\title{
Epitheloid hemangio-endothelioma of right aryepiglottic fold: a rare case report with review of literature
}

\author{
Alpesh D. Fefar*, Paresh J. Khavdu, Mukesh N. Dodia, Sejal N. Mistry, Manish R. Mehta
}

Department of Otorhinolaryngology (ORL), P. D. U. Medical College, Rajkot, Gujarat, India

Received: 21 September 2015

Accepted: 02 October 2015

\author{
*Correspondence: \\ Dr. Alpesh D. Fefar, \\ E-mail: alpay.dr@gmail.com
}

Copyright: () the author(s), publisher and licensee Medip Academy. This is an open-access article distributed under the terms of the Creative Commons Attribution Non-Commercial License, which permits unrestricted non-commercial use, distribution, and reproduction in any medium, provided the original work is properly cited.

\begin{abstract}
Epitheloid hemangio-endothelioma is a very rare tumour of intermittent malignancy of vascular origin, having a tendency to recur with rare incidence of metastasis. The tumour is intermediate between haemangioma and angiosarcoma, mainly affecting liver, lung as well as bones, skin, penis, ovary, scalp, or any part of the body. Internet search was made with the key words epitheloid hemangio-endothelioma and epitheloid hemangio-endothelioma of Larynx, since now only single case has been reported from larynx involving subglottis. Hence we report this rare entity with involvement of the larynx (Sub site: Rt. Aryepiglottic fold) describing clinical and histopathological characteristic. This is perhaps the first case of epitheloid hemangio-endothelioma involving aryepiglottic fold.
\end{abstract}

Keywords: Epitheloid hemangio-endothelioma, Aryepiglottic fold, Larynx

\section{INTRODUCTION}

Epitheloid hemangio-endothelioma is a very rare tumour of intermittent malignancy of vascular origin, having a tendency to recur with rare incidence of metastasis. The tumour is intermediate between haemangioma and angiosarcoma, mainly affecting liver, lung as well as bones, skin, penis, ovary, scalp, or any part of the body. Internet search was made with the key words epitheloid hemangio-endothelioma and epitheloid hemangioendothelioma of larynx, since now only single case has been reported from larynx involving subglottis. ${ }^{1}$ Hence we report this rare entity with involvement of the larynx (Rt. aryepiglottic fold) describing clinical and histopathological characteristic with review of literature. This is the first case of epitheloid hemangioendothelioma involving aryepiglottic fold.

\section{CASE REPORT}

A male patient 35 years old presented in our department with chief complains of difficulty in swallowing to solids increasing progressively, dyspnoea, hoarseness of voice for 5 months. He underwent laryngoscopy which is suggestive of right pyriform fossa mass, followed by Contrast CT scan of neck which confirmed right pyriform fossa soft tissue density lesion of $24 \times 21 \times 27 \mathrm{~mm}$ with involvement of right aryepiglottic fold. No cervical lymphadenopathy noted. Routine haematological investigations were within normal limits. Patient was planned for micro laryngeal LASER surgery, pedunculated greyish white solid mass obscuring right pyriform fossa was seen which was arising from right aryepiglottic fold, excised with diode laser, sent for histopathological examination. The histopathology report states presence of histiocytoid, epitheloid, and spindle tumour cells arranged predominantly perivascularly having vacuolated cytoplasm at places with focal myxoid area and moderate atypia.

Final diagnosis of epitheloid hemangio-endothelioma was made. At 9 months follow up patient is well without any complains. 


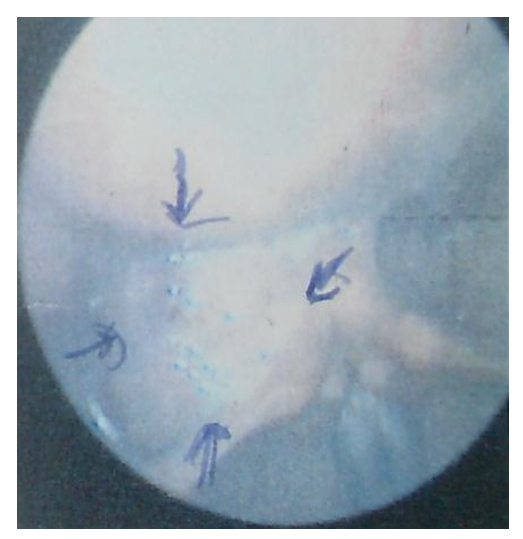

Figure 1: Endoscopy picture. (Arrows showing mass in Rt. pyriform fossa).

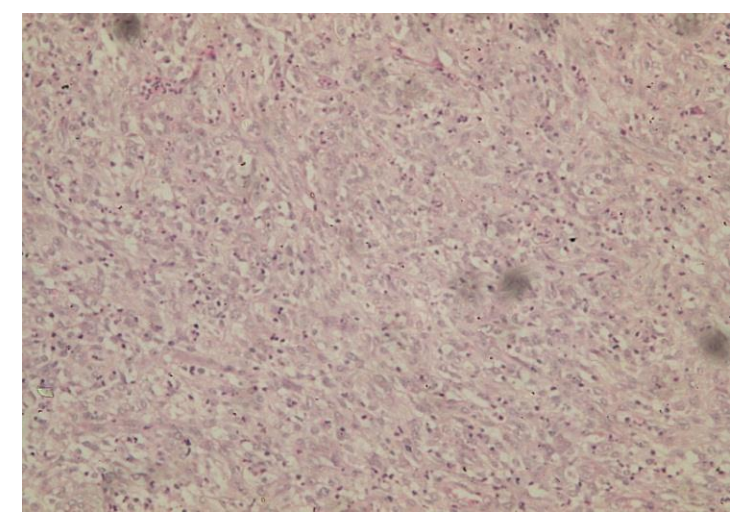

Figure 2: Histo-pathological features of epitheloid hemangio-endothelioma, H \& E staining.

\section{DISCUSSION}

Epitheloid hemangio-endothelioma is a very rare tumour of intermittent malignancy of vascular origin, have a tendency to recur with rare incidence of metastasis. ${ }^{1}$ EHE is a distinct entity that was first described by Weiss and Enzinger in $1982^{2}$ and studied in detail by Ishak et al. in 1984 who described 32 cases. $^{3}$ However, a decade and a half later in 1999, Makhlouf et al. reported the largest series of 137 cases. $^{4}$ EHE is a rare vascular tumor that is intermediate in morphological features between hemangioma and conventional angiosarcoma. EHE has been reported in the liver, lung, gastrointestinal tract, head, neck, central nervous system, heart, bone, and skin. ${ }^{5-13}$ Liver and lung lesions are more common in females, whereas tumors of the bone and soft tissues have an equal sex distribution. ${ }^{14}$ Epitheloid hemangioendothelioma rarely affects head and neck, larynx still rare. Single case had been reported in the literature of epitheloid hemangio-endothelioma of larynx. Immunohisochemical analysis reveals that epitheloid hemangioendothelioma expressed platelet endothelial cell adhesion molecule 1 transmembrane glycoprotein (CD31), cytokeratin CD34, factor VIII-related antigen, vimentin, and occasionally AE1/AE3. Tumor cells are negative for epithelial membrane antigen and carcinoembryonic antigen. ${ }^{1}$ Treatment is wide surgical excision.

\section{CONCLUSION}

This case report is unique as it documents the clinical and pathological features, surgical and postoperative treatment, and long-term follow-up required for a patient with epitheloid hemangio-endothelioma. Although it is very rare tumour, it should be kept in differential diagnosis as treatment options vary.

\section{ACKNOWLEDGMENTS}

We are thankful to Dr. Rajesh Vishwakarma, Prof and Head, Dept. of E. N. T., B. J. Medical College, Ahmedabad, India for critical review and inputs.

Funding: No funding sources

Conflict of interest: None declared

Ethical approval: Not required

\section{REFERENCES}

1. Pinto José Antonio, Fernandes Lis Tozatti, El Ibrahim Roberto. Epithelioid hemangioendothelioma of larynx. Revista Brasileira de Cirurgia da Cabeça e Pescoço. 1993;17(3):17982.

2. Weiss SW, Enzinger FM. Epithelioid hemangioendothelioma: a vascular tumor often mistaken for carcinoma. Cancer. 1982;50:970-81.

3. Ishak KG, Sesterhenn IA, Goodman ZD, Rabin L, Stromeyer FW. Epithelioid hemangioendothelioma of the liver: a clinicopathologic and follow-up study of 32 cases. Hum Pathol. 1984;15:839-52.

4. Makhlouf HR, Ishak KG, Goodman ZD. Epithelioid hemangioendothelioma of the liver: a clinicopathologic study of 137 cases. Cancer. 1999;85:562-82.

5. Dial DH, Liebow AA, Gmelich JT, Friedman PJ, Miyai K, Myer W, et al. Intravascular, bronchiolar, and alveolar tumor of the lung (IVBAT): an analysis of twenty cases of a peculiar sclerosing endothelial tumor. Cancer. 1983;51:452-64.

6. Elias KR, Ryan CK. Epithelioid hemangioendothelioma and the elusive vacuole. Liver Transpl. 2003;9:310-2.

7. Fryer JA, Biggs MT, Katz IA, Brazier DH, Shakespeare TP. Intracranial epithelioid hemangioendothelioma arising at site of previously atypical meningioma. Pathology. 1998;30:95-9.

8. Hamlat A, Casallo-Quilliano C, Saikali S, Lesimple T, Brassier G. Epithelioid hemangiendothelioma of the infundibular-hypothalamic region: case report and literature review. J Neurooncol. 2004;67:361-6.

9. Chow L, Chow W, Fong DT. Epithelioid hemangioendothelioma of the brain. Am J Surg Pathol. 1992;16:619-25.

10. Lee JC, Lee BJ, Wang SG, Kim HW. Epithelioid haemangioendothelioma in the parapharyngeal space. J Laryngol Otol. 2006;120:505-7. 
11. Safirstein J, Aksenov S, Smith F. Cardiac epithelioid hemangioendothelioma with 8-year follow-up. Cardiovasc Pathol. 2007;16:183-6.

12. Kleer CG, Unni KK, Mcleod RA. Epithelioid hemangioendothelioma of bone. Am J Surg Pathol. 1996;20:1301-11.

13. Quante M, Patel NK, Hill S, Merchant W, Courtauld E, Newman $P$, et al. Epithelioid hemangioendothelioma presenting in the skin: a clinicopathologic study of eight cases. Am J Dermatopathol. 1998 Dec;20(6):541-6.
14. Weiss SW, Goldblum J, Enzinger FM. Liver and lung lesions. In: Weiss SW, Goldblum J, Enzinger FM, eds. Enzinger and Weiss' Soft Tissue Tumors. 4th ed. Philadelphia, PA: Mosby; 2001: 891-914.

Cite this article as: Fefar $\mathrm{AD}$, Khavdu PJ, Dodia MN, Mistry SN, Mehta MR. Epitheloid hemangioendothelioma of right aryepiglottic fold: a rare case report with review of literature. Int J Otorhinolaryngol Head Neck Surg 2015;1:93-5. 